\title{
Does Evidence Exist to Blunt Inflammatory Response by Nutraceutical Supplementation during COVID-19 Pandemic? An Overview of Systematic Reviews of Vitamin D, Vitamin C, Melatonin, and Zinc
}

\author{
Salvatore Corrao ${ }^{1,2} *$ (D) , Raffaella Mallaci Bocchio ${ }^{2}$, Marika Lo Monaco ${ }^{2}$, Giuseppe Natoli ${ }^{2}$ (D), Attilio Cavezzi ${ }^{3}$ (D), \\ Emidio Troiani ${ }^{4}$ and Christiano Argano ${ }^{2}$
}

1 Department of Health Promotion Sciences, Maternal and Infant Care, Internal Medicine and Medical Specialties, [PROMISE], University of Palermo, 90127 Palermo, Italy

2 COVID Unit, Department of Internal Medicine, National Relevance and High Specialization Hospital Trust ARNAS Civico, Di Cristina, Benfratelli, 90127 Palermo, Italy; raffaellamallacibocchio@gmail.com (R.M.B.); marika.lomonaco@hotmail.it (M.L.M.); peppenatoli@gmail.com (G.N.); chargano@yahoo.it (C.A.)

3 Eurocenter Venalinfa, 63074 San Benedetto del Tronto, Italy; info@cavezzi.it

4 Cardiology Unit, State Hospital, Social Security Institute, 20, 47893 Cailungo, San Marino; emidio.troiani@iss.sm

* Correspondence: s.corrao@tiscali.it or salvatore.corrao@unipa.it; Tel.: +39-340-590-7183

Citation: Corrao, S.; Mallaci Bocchio, R.; Lo Monaco, M.; Natoli, G.; Cavezzi, A.; Troiani, E.; Argano, C. Does Evidence Exist to Blunt Inflammatory Response by Nutraceutical Supplementation during COVID-19 Pandemic? An Overview of Systematic Reviews of Vitamin D, Vitamin C, Melatonin, and Zinc. Nutrients 2021, 13, 1261. https://doi.org/10.3390/nu13041261

Academic Editor: Rosa Casas

Received: 12 March 2021

Accepted: 6 April 2021

Published: 12 April 2021

Publisher's Note: MDPI stays neutral with regard to jurisdictional claims in published maps and institutional affiliations.

Copyright: (C) 2021 by the authors Licensee MDPI, Basel, Switzerland. This article is an open access article distributed under the terms and conditions of the Creative Commons Attribution (CC BY) license (https:// creativecommons.org/licenses/by/ $4.0 /)$.

\begin{abstract}
More than one year has passed since the first cases of coronavirus disease 2019 (COVID-19) caused by severe acute respiratory syndrome (SARS)-CoV-2 coronavirus were reported in Wuhan (China), rapidly evolving into a global pandemic. This infectious disease has become a major public health challenge in the world. Unfortunately, to date, no specific antivirals have been proven to be effective against COVID-19, and although a few vaccines are available, the mortality rate is not decreasing but is still increasing. One therapeutic strategy has been focused on infection prevention and control measures. In this regard, the use of nutraceutical supports may play a role against some aspect of the infection, particularly the inflammatory state and the immune system function of patients, thus representing a strategy to control the worst outcomes of this pandemic. For this reason, we performed an overview including meta-analyses and systematic reviews to assess the association among melatonin, vitamin $C$, vitamin D, zinc supplementation and inflammatory markers using three databases, namely, MEDLINE, PubMed Central and the Cochrane Library of Systematic Reviews. According to the evidence available, an intake of 50,000 IU/month of vitamin D showed efficacy in CRP. An amount of 1 to $2 \mathrm{~g}$ per day of vitamin C demonstrated efficacy both in CRP and endothelial function, and a dosage of melatonin ranging from 5 to $25 \mathrm{mg}$ / day showed good evidence of efficacy in CRP, TNF and IL6. A dose of $50 \mathrm{mg}$ /day of elemental zinc supplementation showed positive results in CRP. Based on the data reported in this review, the public health system could consider whether it is possible to supplement the current limited preventive measures through targeted nutraceutical large-scale administration.
\end{abstract}

Keywords: COVID-19; SARS-CoV-2; overview; systematic review; vitamin D; vitamin C; melatonin; zinc; inflammation; nutraceuticals

\section{Introduction}

The coronavirus disease 2019 (COVID-19), caused by SARS-CoV-2, has rapidly spread worldwide. The clinical spectrum of SARS-CoV-2 severity may range from asymptomatic to severe conditions, including acute respiratory distress syndrome and sometimes leading to multiorgan failure. For most people, a piece of important information is to know how to strengthen the immune system to prevent SARS-CoV-2 infection to avoid the next waves of the deadly COVID-19 pandemic [1]. It is well known that the presence of chronic diseases 
may exacerbate the inflammatory response induced by coronavirus disease, increasing the risk of severe disease and mortality. In this respect, systemic inflammation developing in people with non-communicable diseases, such as diabetes, tends to exacerbate the respiratory symptoms of infection [2]. Additionally, obesity and central adiposity represent important risk factors for complications of COVID-19, especially in patients with impaired heart and lung function [3]. Furthermore, the vascular damage frequent in diabetic patients and people with hypertension increases the risk of these individuals being affected by COVID-19 thrombotic complications. The latest report issued by WHO mentioned more than 96 million confirmed cases and more than two million deaths worldwide [4]. To reduce the risk of transmission of SARS-CoV-2, several preventive measures have been advised for general public health, including hand and respiratory hygiene and safe food practices (concerning raw animal products) to reduce the risk of transmission of SARSCoV-2 [5]. The use of both a correct life-style and nutraceutical supports of proven efficacy may play a role against some aspect of the infection, thus representing a strategy to control this epidemic. In the current situation, it is urgent to propose preventive health measures to reduce the risk of COVID-19 infection in addition to an adequate vaccine diffusion and/or effective antiviral drugs. In the COVID-19 pandemic, the importance of adequate nutrition and eating habits has been widely emphasized, not only to reduce the impact of the widely diffused non-communicable diseases that may cause more severe infections (e.g., diabetes and obesity) but also as a way to regulate the inflammatory state of patients. In fact, underestimating the importance of nutrition for COVID-19 patients will significantly affect the prognosis of these subjects [6]. Vitamins $C$ and D and trace elements, including zinc [7], may play a fundamental role in disease susceptibility and maintaining immune system function [8]. In fact, COVID-19 is characterized by high levels of inflammatory markers, including C-reactive protein (CRP) and increased levels of inflammatory cytokines and chemokines $[9,10]$. Any nutritional/nutraceutical approach potentially useful to regulate immune function may consequently be beneficial both in the early phase, when an adequate immune reaction is fundamental, and in case of later cytokine storm, when the hyper-reactive immunity may be detrimental. This overview aims to analyze the current knowledge from systematic reviews of the relationship between nutraceutical supports and the reduction in inflammatory response to formulate clinical recommendations and highlight directions for future research during the COVID-19 pandemic. The influence of nutraceutical compounds on inflammatory markers will be addressed.

\section{Materials and Methods}

\subsection{Eligibility Criteria}

All meta-analyses and systematic reviews (SRs) regarding the association among melatonin, vitamin C, vitamin D, zinc supplementation and inflammatory markers were eligible for this overview.

\subsection{Search Methods}

On 22 September 2020, at 10:06 a.m. (GMT -5, Bethesta, MA, USA), a literature search was performed, regarding MEDLINE, PubMed Central and the Cochrane Library of Systematic Reviews (CLSR) and using the following search strings.

\subsubsection{Melatonin}

("melatonin" [MeSH Terms] OR "melatonin" [All Fields] OR "melatonin s" [All Fields] OR "melatonin" [All Fields] OR "melatonins" [ All Fields]) AND ("inflammatories" [All Fields] OR "inflammatory" [All Fields] OR ("inflammation" [MeSH Terms] OR "inflammation" [All Fields] OR "inflammations" [All Fields] OR "inflammation s "[All Fields]) OR" TNF "[All Fields] OR (" interleukine "[All Fields] OR" interleukines "[All Fields] OR" interleukins "[MeSH Terms] OR" interleukins "[All Fields] OR" interleukin "[All Fields]) OR (" cytokin "[All Fields] OR" cytokine s "[All Fields] OR" cytokines "[MeSH Terms] OR" 
cytokines "[All Fields] OR" cytokine "[All Fields] OR" cytokinic "[All Fields] OR" cytokins "[All Fields])).

\subsubsection{Vitamin C}

("ascorbic acid" [MeSH Terms] OR ("ascorbic" [All Fields] AND "acid" [All Fields]) OR "ascorbic acid" [All Fields] OR " vitamin c "[All Fields] OR (" ascorbate "[All Fields] OR" ascorbates "[All Fields] OR" ascorbic "[All Fields]) OR (" ascorbate "[All Fields] OR" ascorbates "[All Fields] OR "ascorbic" [All Fields])) AND ("inflammation" [MeSH Terms] OR "inflammation" [All Fields] OR "inflammations" [All Fields] OR "inflammation s" [All Fields] OR ("inflammatories" [ All Fields] OR "inflammatory" [All Fields]) OR "TNF" [All Fields] OR ("interleukine" [All Fields] OR "interleukines" [All Fields] OR "interleukins" [MeSH Terms] OR "interleukins" [ All Fields] OR "interleukin" [All Fields]) OR ("cytokin" [All Fields] OR "cytokine s" [All Fields] OR "cytokines" [MeSH Terms] OR "cytokines" [All Fields] OR "cytokine" [All Fields] OR "cytokinic" [All Fields] OR "cytokins" [All Fields])).

\subsubsection{Vitamin D}

("vitamin d" [MeSH Terms] OR "vitamin d" [All Fields] OR "ergocalciferols" [MeSH Terms] OR "ergocalciferols" [All Fields] OR ("ergocalciferols "[MeSH Terms] OR" ergocalciferols "[All Fields] OR" ergocalciferol "[All Fields]) OR (" cholecalciferol "[MeSH Terms] OR" cholecalciferol "[All Fields] OR" cholecalciferols "[All Fields] OR" colecalciferol "[All Fields]) OR (" calcitriol "[MeSH Terms] OR" calcitriol "[All Fields] OR" calcitriols "[All Fields])) AND (" inflammation "[MeSH Terms] OR" inflammation "[All Fields] OR "inflammations" [All Fields] OR "inflammation s" [All Fields] OR ("inflammatories" [All Fields] OR "inflammatory" [All Fields]) OR "TNF" [All Fields] OR ("interleukine" [All Fields] OR "interleukines" [All Fields] OR "interleukins" [MeSH Terms] OR "interleukins" [All Fi elds] OR "interleukin" [All Fields]) OR ("cytokin" [All Fields] OR "cytokine s" [All Fields] OR "cytokines" [MeSH Terms] OR "cytokines" [All Fields] OR "cytokine" [ All Fields] OR "cytokinic" [All Fields] OR "cytokins" [All Fields])).

\subsubsection{Zinc}

("zinc" [MeSH Terms] OR "zinc" [All Fields]) AND ("inflammation" [MeSH Terms] OR "inflammation" [All Fields] OR "inflammations" [All Fields] OR "inflammation s" [All Fields] OR ("inflammatories" [All Fields] OR "inflammatory" [All Fields]) OR "TNF" [All Fields] OR ("interleukine" [All Fields] OR "interleukines "[All Fields] OR" interleukins "[MeSH Terms] OR" interleukins "[All Fields] OR" interleukin "[All Fields]) OR (" cytokin "[All Fields] OR" cytokine s "[All Fields] OR "cytokines" [MeSH Terms] OR "cytokines" [All Fields] OR "cytokine" [All Fields] OR "cytokinic" [All Fields] OR "cytokins" [All Fields])).

Mesh terms were not used to search the CLSR.

\subsection{Study Selection}

Two reviewers (RMB and MLM) independently reviewed the titles, abstracts and full texts for their potential inclusion against the eligibility criteria. Any disagreement was resolved by discussion with a third reviewer (SC). In cases where information about a study's eligibility was limited or incomplete (for instance, when only an abstract was accessible), the authors of the study were contacted to request the full text or further details.

\subsection{Data Extraction, Coding and Analysis}

Two authors (MBR and LMM) collected data from all included articles using a pretested form and individuated duplicates, and prepared the flow-chart of excluded and included studies (Figure 1). SC and CA independently verified the entire process. 

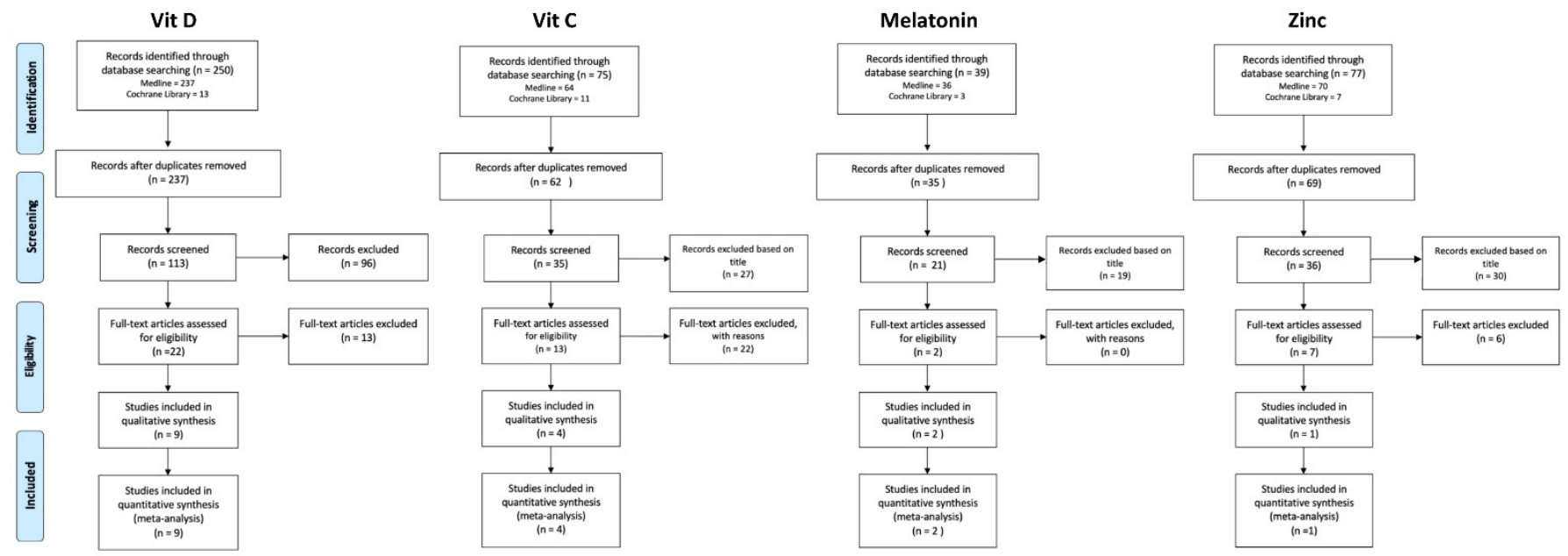

Figure 1. Flow diagram of the study selection process.

\subsection{Quality Assessment of Included Reviews}

Two authors (RMB and MLM) assessed the quality of the included systematic reviews by A Measurement Tool to Checklist Assess Systematic Reviews (AMSTAR). AMSTAR is a comprehensive validated tool to assess the methodological quality of SRs. It includes 11 domains, like the a priori protocol documentation, scientific quality and risk assessment publication bias. Based on AMSTAR evaluations, we ordered the AMSTAR scores into tertiles and classified the methodological quality of the single identified reviews in three categories: "high" (8-11 points out of 11), "moderate" (4-7 points) and "low" (3 or fewer points (Figure 2).

\begin{tabular}{|c|c|c|}
\hline Nutraceutics & STUDY & QUALITY \\
\hline \multirow{9}{*}{ Vitamin D } & Omid Asbaghia (2019) [11] & \\
\hline & Sheila A. FisherID (2019) [12] & \\
\hline & Mingming Wanga (2019) [13] & \\
\hline & Yanting Yu (2018) [14] & \\
\hline & Mohsen Mazidi (2018) [15] & \\
\hline & EK Calton (2018) [16] & \\
\hline & Tari Agbalalah (2017) [17] & \\
\hline & Małgorzata Jamka (2015) [18] & \\
\hline & Neng Chen (2014) [19] & \\
\hline \multirow{4}{*}{ Vitamin C } & Maryam Safa bakhsh (2019) [20] & \\
\hline & Sadegh Jafarnejad (2018) [21] & \\
\hline & Ammar W. Ashor (2015) [22] & \\
\hline & Ammar W. Ashor (2014) [23] & \\
\hline \multirow{2}{*}{ Melatonin } & Zarezadeh M (2019) [24] & \\
\hline & Akbari M (2018) [25] & \\
\hline Zinc & Mousavi SM (2018) [26] & \\
\hline
\end{tabular}

Figure 2. A Measurement Tool to Checklist Assess Systematic Reviews (AMSTAR) assessment for each systematic review, sorted by year of publication. Colors are referred to scores: green is referred to "high scores" (8-11 points) and yellow to "moderate" (4-7 points). No systematic review had a "low" (<3 points) evaluation. 


\subsection{Dosage of Nutraceuticals}

Data were extracted from each trial of the included systematic reviews/meta-analyses, and they were tabulated according to the results of each trial. We did not tabulate vitamin $\mathrm{D}$ dosage due to the great heterogeneity among trials.

\section{Results}

No SR regarding the four compounds was of low quality.

The punctual evaluation is reported in the Supplementary Materials.

Regarding vitamin D (Table 1), several SRs were taken into consideration, and they were heterogenous in different aspects: patient characteristics, type of treatment, end-points and measured variables.

However, this heterogeneity enriched the final analysis. Nine SRs were included, with a follow-up duration between 1,5 month and 3 years. The diabetic patients were mostly represented, but different categories of patients were considered, including those affected by HIV, obese, elderly or featuring a high cardiovascular risk. Six out of nine SRs demonstrated a clear efficacy of CRP reduction. Only one SR showed a reduction in interleukin-6 (IL6).

Table 2 shows the variable dosages used in each study, but an average of 50.000 units of ergocalciferol monthly were administered to patients.

Regarding vitamin C (Table 3), four SRs showed an effective action on the endothelial function and CRP reduction with an intervention duration between 1 day and 52 weeks. The diabetic patients, subjects with chronic diseases and adult participants aged 18 years and older were considered. Two out of four SRs proved to be effective in reducing CRP levels. The other two SRs showed beneficial effects on endothelial function. 
Table 1. Vitamin D: characteristics of the included systematic reviews.

\begin{tabular}{|c|c|c|c|c|c|c|c|c|c|}
\hline Study & $\begin{array}{l}\text { Omid Asbaghia } \\
\text { (2019) [11] }\end{array}$ & $\begin{array}{l}\text { Sheila A. FisherID (2019) } \\
\text { [12] }\end{array}$ & $\begin{array}{l}\text { Mingming Wanga } \\
\text { (2019) [13] }\end{array}$ & Yanting Yu (2018) [14] & $\begin{array}{l}\text { Mohsen Mazidi } \\
\quad \text { (2018) [15] }\end{array}$ & $\begin{array}{l}\text { EK Calton (2018) } \\
{[16]}\end{array}$ & $\begin{array}{l}\text { Tari Agbalalah } \\
\text { (2017) [17] }\end{array}$ & $\begin{array}{c}\text { Małgorzata } \\
\text { Jamka (2015) } \\
{[18]}\end{array}$ & $\begin{array}{l}\text { Neng Chen (2014) } \\
\text { [19] }\end{array}$ \\
\hline $\begin{array}{l}\text { Databases } \\
\text { searched }\end{array}$ & $\begin{array}{l}\text { PubMed, Scopus, ISI } \\
\text { Web of Science and } \\
\text { Google Scholar }\end{array}$ & $\begin{array}{l}\text { Central, Medline, ENBASE, } \\
\text { PubMed and Web of } \\
\text { Science }\end{array}$ & $\begin{array}{c}\text { PubMed, } \\
\text { EMBASE, and } \\
\text { Cochrane Library }\end{array}$ & $\begin{array}{l}\text { PubMed and the } \\
\text { Cochrane Library }\end{array}$ & $\begin{array}{l}\text { PubMed-Medline, } \\
\text { SCOPUS, Google } \\
\text { Scholar and Web of } \\
\text { Science }\end{array}$ & $\begin{array}{l}\text { SCOPUS and } \\
\text { PubMed }\end{array}$ & $\begin{array}{l}\text { Cochrane, } \\
\text { PubMed and } \\
\text { Medline }\end{array}$ & $\begin{array}{l}\text { PubMed, } \\
\text { Scopus, the } \\
\text { Cochrane } \\
\text { Library and } \\
\text { EMBASE }\end{array}$ & $\begin{array}{l}\text { PubMed, Web of } \\
\text { Science, and } \\
\text { Cochrane library }\end{array}$ \\
\hline Articles included & 8 & 8 & 14 & 13 & 24 & 9 & 29 & 13 & 10 \\
\hline $\begin{array}{l}\text { Type of patients } \\
\text { analyzed }\end{array}$ & $\begin{array}{l}\text { Healthy subjects and } \\
\text { patients with } \\
\text { colorectal adenoma, } \\
\text { type } 2 \text { diabetes } \\
\text { mellitus, pregnancy, } \\
\text { pregnancy with } \\
\text { gestational diabetes } \\
\text { and polycystic ovary } \\
\text { syndrome }\end{array}$ & $\begin{array}{l}\text { Patients with type1 } \\
\text { diabetes, Addison's disease, } \\
\text { multiple sclerosis, asthma } \\
\text { and healthy subjects }\end{array}$ & $\begin{array}{l}\text { Patients with } \\
\text { asthma }\end{array}$ & $\begin{array}{l}\text { Patients with type } \\
2 \text { diabetes }\end{array}$ & $\begin{array}{l}\text { Patients with obesity, } \\
\text { type } 2 \text { diabetic, } \\
\text { HIV-infected, } \\
\text { non-diabetic chronic } \\
\text { kidney disease } \\
\text { chronic fatigue } \\
\text { syndrome, } \\
\text { non-alcoholic fatty } \\
\text { liver disease and } \\
\text { healthy pregnant. }\end{array}$ & $\begin{array}{c}\text { Patients } \geq 60 \text { years, } \\
\text { overweight and } \\
\text { obese, prediabetes, } \\
\text { non-alcoholic fatty } \\
\text { liver disease, } \\
\text { myocardial } \\
\text { infarction, isolated } \\
\text { systolic } \\
\text { hypertension, } \\
\text { postmenopausal } \\
\text { women. }\end{array}$ & $\begin{array}{c}\text { Patients with type } \\
2 \text { and gestational } \\
\text { diabetes melli- } \\
\text { tus/prediabetic, } \\
\text { cardiovascular } \\
\text { disease, chronic } \\
\text { kidney disease } \\
\text { and } \\
\text { overweight/obese } \\
\text { participants }\end{array}$ & $\begin{array}{l}\text { Obese and } \\
\text { overweight } \\
\text { subjects }\end{array}$ & $\begin{array}{c}\text { Healthy subjects and } \\
\text { patients with type } 2 \\
\text { diabetes, polycystic } \\
\text { ovary syndrome } \\
\text { women, obese } \\
\text { adults, coronary } \\
\text { artery disease } \\
\text { patients }\end{array}$ \\
\hline Posology & $\begin{array}{ll}\text { - } & 500 \mathrm{mg} / \mathrm{d} \mathrm{Ca} \\
\text { citrate }+ \\
200 \mathrm{IU} / \text { day } \\
\text { vit D } \\
1000 \mathrm{mg} / \mathrm{d} \mathrm{Ca} \\
\text { citrate }+ \\
50,000 \mathrm{IU} / \text { day } \\
\text { vit D }\end{array}$ & 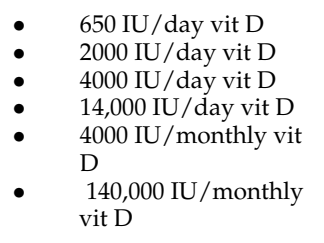 & 500 UI/day vit D & $\begin{array}{ll}- & 200 \mathrm{IU} / \text { day vit } \mathrm{D} \\
\bullet & 6.000 \mathrm{IU} / \text { day vit } \mathrm{D} \\
& 25.000 \mathrm{IU} / \text { day vit } \\
\mathrm{D} & \mathrm{D} \\
& 50.000 \mathrm{IU} / \text { week vit } \\
& \mathrm{D}\end{array}$ & $\begin{array}{l}400 \mathrm{IU} / \text { day to } \\
11200 \mathrm{IU} / \text { day vit D }\end{array}$ & $\begin{array}{l}200 \mathrm{IU} / \text { day to } \\
11200 \mathrm{IU} / \text { day vit D }\end{array}$ & $\begin{array}{c}4000 \mathrm{IU} / \text { weeks vit } \\
\text { D }\end{array}$ & $\begin{array}{l}1000 \mathrm{IU} / \text { day to } \\
7000 \mathrm{IU} / \text { day vit } \\
\text { D }\end{array}$ & $\begin{array}{c}400 \mathrm{IU} / \text { day to } \\
7000 \mathrm{IU} / \text { day vit D }\end{array}$ \\
\hline $\begin{array}{l}\text { Intervention } \\
\text { duration range }\end{array}$ & 6 weeks -3 years & 3-12 months & $1,5-12$ months & 8-52 weeks & 4 weeks-12 months & $12-52$ weeks & 8-52 weeks & 4-52 weeks & 9-48 weeks \\
\hline
\end{tabular}


Table 1. Cont.

\begin{tabular}{|c|c|c|c|c|c|c|c|c|c|}
\hline Study & $\begin{array}{l}\text { Omid Asbaghia } \\
\text { (2019) [11] }\end{array}$ & $\begin{array}{c}\text { Sheila A. FisherID } \\
\text { (2019) [12] }\end{array}$ & $\begin{array}{c}\text { Mingming Wanga } \\
\text { (2019) [13] }\end{array}$ & $\begin{array}{c}\text { Yanting Yu (2018) } \\
\text { [14] }\end{array}$ & $\begin{array}{c}\text { Mohsen Mazidi } \\
\text { (2018) [15] }\end{array}$ & $\begin{array}{c}\text { EK Calton (2018) } \\
{[16]}\end{array}$ & $\begin{array}{c}\text { Tari Agbalalah } \\
\text { (2017) [17] }\end{array}$ & $\begin{array}{l}\text { Małgorzata Jamka } \\
\text { (2015) [18] }\end{array}$ & $\begin{array}{c}\text { Neng Chen (2014) } \\
{[19]}\end{array}$ \\
\hline Endpoint & $\begin{array}{l}\text { The effect of vitamin } \\
\text { D-calcium } \\
\text { co-supplementation } \\
\text { on inflammatory } \\
\text { biomarkers in adults }\end{array}$ & $\begin{array}{l}\text { The effect of vitamin } \\
\text { D supplementation } \\
\text { in enhancing } \\
\text { absolute T } \\
\text { regulatory cells } \\
\text { (Treg) numbers in } \\
\text { patients with } \\
\text { inflammatory or } \\
\text { autoimmune } \\
\text { disease. }\end{array}$ & $\begin{array}{c}\text { To assess the } \\
\text { correlations of } \\
\text { vitamin D status } \\
\text { with asthma- related } \\
\text { respiratory } \\
\text { outcomes. }\end{array}$ & $\begin{array}{l}\text { To examine whether } \\
\text { or not the } \\
\text { supplementation of } \\
\text { vitamin D exhibits } \\
\text { anti-inflammatory } \\
\text { benefits in T2DM } \\
\text { subjects }\end{array}$ & $\begin{array}{c}\text { To evaluate the effect } \\
\text { of vitamin D } \\
\text { supplementation on } \\
\text { C-reactive protein } \\
\text { (CRP) }\end{array}$ & $\begin{array}{c}\text { Causal links } \\
\text { between vitamin D } \\
\text { status [25(OH)D] } \\
\text { and systemic } \\
\text { inflammation }\end{array}$ & $\begin{array}{c}\text { The effects of } \\
\text { vitamin D } \\
\text { supplementation on } \\
\text { endothelial function } \\
\text { and inflammation in } \\
\text { adults }\end{array}$ & $\begin{array}{l}\text { The effect of } \\
\text { supplementation } \\
\text { with vitamin D on } \\
\text { selected } \\
\text { inflammatory } \\
\text { biomarkers in } \\
\text { overweight and } \\
\text { obese subjects. }\end{array}$ & $\begin{array}{l}\text { To evaluate the } \\
\text { association of } \\
\text { vitamin D } \\
\text { supplementation } \\
\text { with circulating } \\
\text { hs-CRP levels. }\end{array}$ \\
\hline Conclusions* & $\begin{array}{c}\text { Vitamin D-calcium } \\
\text { co-supplementation } \\
\text { has beneficial effect } \\
\text { on serum CRP } \\
\text { concentrations. A } \\
\text { beneficial effect was } \\
\text { not seen for IL-6 and } \\
\text { TNF- } \alpha \\
\text { concentrations. }\end{array}$ & $\begin{array}{c}\text { Vitamin D } \\
\text { supplementation } \\
\text { may increase } \\
\text { Treg/CD3 ratios in } \\
\text { both healthy } \\
\text { individuals and } \\
\text { patients with } \\
\text { autoimmune } \\
\text { disorders and may } \\
\text { increase Treg } \\
\text { function. }\end{array}$ & $\begin{array}{l}\text { Vitamin D } \\
\text { supplementation } \\
\text { reduced the rate of } \\
\text { asthma exacerbation, } \\
\text { especially in patients } \\
\text { with vitamin D } \\
\text { insufficiency. }\end{array}$ & $\begin{array}{l}\text { In T2DM subjects, } \\
\text { vitamin D } \\
\text { supplementation is } \\
\text { beneficial for the } \\
\text { reduction in hs-CRP } \\
\text { but does not have a } \\
\text { significant influence } \\
\text { on TNF- } \alpha \text { and IL-6. }\end{array}$ & $\begin{array}{c}\text { Vitamin D } \\
\text { supplementation } \\
\text { had no impact on } \\
\text { serum CRP, IL10, } \\
\text { and TNF- } \alpha \text {, while } \\
\text { significantly } \\
\text { increased serum IL6. }\end{array}$ & $\begin{array}{c}\text { Available } \\
\text { high-quality RCTs } \\
\text { did not support a } \\
\text { beneficial effect of } \\
\text { cholecalciferol on } \\
\text { systemic IL-6 and } \\
\text { CRP. }\end{array}$ & $\begin{array}{l}\text { The use of vitamin } \mathrm{D} \\
\text { supplementation as } \\
\text { a therapeutic or } \\
\text { preventative } \\
\text { measure for CVD is } \\
\text { not supported by } \\
\text { evidence. }\end{array}$ & $\begin{array}{c}\text { Supplementation } \\
\text { with vitamin D does } \\
\text { not have a } \\
\text { significant influence } \\
\text { on changes in the } \\
\text { concentration of } \\
\text { selected } \\
\text { inflammatory } \\
\text { biomarkers in the } \\
\text { obese and } \\
\text { overweight subjects. }\end{array}$ & $\begin{array}{l}\text { Vitamin D } \\
\text { supplementation is } \\
\text { beneficial for the } \\
\text { reduction in } \\
\text { circulating hs-CRP. }\end{array}$ \\
\hline
\end{tabular}

* Author's conclusions are reported. 
Table 2. Vitamin D: summary of the principal characteristics of the included systematic reviews.

\begin{tabular}{|c|c|c|c|c|c|c|}
\hline Pharmace & cal Drug & Dose & Follow-Up & Efficacy Yes & Efficacy No & Study \\
\hline \multirow{2}{*}{ Vitamin D1 e D2 } & Paricalcitol & $400 \mathrm{IU}$ day & 3 months & CRP & & $\begin{array}{l}\text { Mohsen Mazidi } \\
\quad(2018) \text { [15] }\end{array}$ \\
\hline & Ergocalciferol & $50.000 \mathrm{IU} /$ month & 12 weeks -6 months & CRP & & $\begin{array}{l}\text { Mohsen Mazidi } \\
\quad(2018) \text { [15] }\end{array}$ \\
\hline \multirow{5}{*}{ Vitamin D3 } & \multirow{5}{*}{ Cholecalciferol } & $\begin{array}{c}\text { 200-6.000 IU/day } \\
25.000-50.000 \mathrm{IU} / \text { week }\end{array}$ & $8-52$ weeks & CRP & TNF- $\alpha$ e IL6 & $\begin{array}{c}\text { Yanting Yu (2018) } \\
\text { [14] }\end{array}$ \\
\hline & & $\begin{array}{l}\text { 400 IU/day- } \\
11,200 \mathrm{IU} / \text { day }\end{array}$ & 4 weeks -12 months & IL6 & $\begin{array}{l}\text { CRP, IL10 e } \\
\text { TNF- } \alpha\end{array}$ & $\begin{array}{l}\text { Mohsen Mazidi } \\
\quad(2018)[15]\end{array}$ \\
\hline & & $4000 \mathrm{IU} /$ week & 8 weeks & & $\begin{array}{l}\text { FMD *, CRP, IL-6 } \\
\text { e TNF- } \alpha\end{array}$ & $\begin{array}{l}\text { Tari Agbalalah } \\
\text { (2017) [17] }\end{array}$ \\
\hline & & $4000 \mathrm{IU} /$ day & 24 weeks & hs-CRP ** & & $\begin{array}{c}\text { Neng Chen (2014) } \\
{[19]}\end{array}$ \\
\hline & & $\leq 4000 \mathrm{IU} /$ day & $>12$ weeks & CRP & TNF- $\alpha$ e IL6 & $\begin{array}{l}\text { Yanting Yu (2018) } \\
\text { [14] }\end{array}$ \\
\hline
\end{tabular}

${ }^{*} \mathrm{FMD}=$ flow-mediated dilation (endothelial function parameters). ${ }^{* *}$ hs-CRP $=$ circulating high-sensitivity C-reactive protein.

Table 3. Vitamin C: characteristics of the included systematic reviews.

\begin{tabular}{|c|c|c|c|c|}
\hline Scheme 2019. & $\begin{array}{l}\text { Maryam Safabakhsh } \\
\text { (2019) [20] }\end{array}$ & $\begin{array}{l}\text { Sedagh Jafamejad (2018) } \\
\text { [21] }\end{array}$ & $\begin{array}{c}\text { Ammar W. Ashor (2015) } \\
\text { [22] }\end{array}$ & $\begin{array}{c}\text { Ammar W. Ashor (2014) } \\
\text { [23] }\end{array}$ \\
\hline Databases searched & $\begin{array}{c}\text { PubMed, Scopus, ISI Web } \\
\text { of Science e Google } \\
\text { Scholar }\end{array}$ & $\begin{array}{c}\text { Scopus, Cochrane Library, } \\
\text { PubMed and Google } \\
\text { Scholar }\end{array}$ & $\begin{array}{l}\text { MEDLINE, Embase, } \\
\text { Cochrane Library and } \\
\text { Scopus }\end{array}$ & $\begin{array}{c}\text { Medline, Embase, } \\
\text { Cochrane Library, and } \\
\text { Scopus }\end{array}$ \\
\hline Articles included & 11 & 12 & 46 & 44 \\
\hline $\begin{array}{l}\text { Type of patients } \\
\text { analyzed }\end{array}$ & $\begin{array}{c}\text { Diabetic } \\
\text { subjects/Nonsmokers }\end{array}$ & $\begin{array}{l}\text { Patients with chronic } \\
\text { diseases }\end{array}$ & $\begin{array}{c}\text { Adult participants }>18 \\
\text { years }\end{array}$ & Adult participants \\
\hline Posology & $500 \mathrm{mg} /$ day & $250 \mathrm{mg} /$ day $-1 \mathrm{~g} /$ day & 500-2000 mg/day & $500 \mathrm{mg} /$ day $-1 \mathrm{~g} /$ day \\
\hline $\begin{array}{l}\text { Intervention duration } \\
\text { range }\end{array}$ & 1 day-8 weeks & 4-24 weeks & 4-52 weeks & 1 day-8 weeks \\
\hline Endpoint & $\begin{array}{l}\text { The effect of vitamin } C \text { on } \\
\text { reducing CRP or hs-CRP } \\
\text { level. }\end{array}$ & $\begin{array}{c}\text { The effects of } \\
\text { supplementation with } \\
\text { vitamin C on serum } \\
\text { C-reactive Protein (CRP) } \\
\text { levels. }\end{array}$ & $\begin{array}{l}\text { The effects of antioxidant } \\
\text { vitamins } C \text { and } E \\
\text { supplementation on } \\
\text { endothelial function. }\end{array}$ & $\begin{array}{l}\text { The effect of } \\
\text { supplementation with } \\
\text { vitamin } C \text { on endothelial } \\
\text { function. }\end{array}$ \\
\hline Results & $\begin{array}{l}\text { Vitamin C could decrease } \\
\text { CRP levels relative to } \\
\text { placebo group } \\
\text { ([WMD] }=-0.73 \mathrm{mg} / \mathrm{L}: \\
95 \% \text { CI: }-1.30 \text { to }-0.15 \\
p=0.013)\end{array}$ & $\begin{array}{l}\text { Supplementation with } \\
\text { vitamin C significantly } \\
\text { lowered CRP among trials. }\end{array}$ & $\begin{array}{l}\text { Significant improvements } \\
\text { in endothelial function } \\
\text { were observed in trials } \\
\text { supplementing with } \\
\text { vitamin C (500-2000 } \\
\text { mg/d) (SMD: 0.25, 95\% } \\
\left.\text { CI 0.02, 0.49, } \frac{1}{4} 0 \cdot 043\right)\end{array}$ & $\begin{array}{c}\text { A beneficial effect of } \\
\text { vitamin } C \text { on endothelial } \\
\text { function was found (SMD } \\
0.50,95 \% \text { CI: } 0.34,0.66 \\
\quad p<0.001)\end{array}$ \\
\hline Conclusions & $\begin{array}{l}\text { Vitamin C } \\
\text { supplementation might } \\
\text { have a significant effect } \\
\text { only on CRP reduction. }\end{array}$ & $\begin{array}{l}\text { Vitamin C } \\
\text { supplementation reduces } \\
\text { serum CRP levels. }\end{array}$ & $\begin{array}{l}\text { Supplementation with } \\
\text { vitamin C improves } \\
\text { endothelial function. }\end{array}$ & $\begin{array}{l}\text { Supplementation with } \\
\text { vitamin } C \text { improved } \\
\text { endothelial function. }\end{array}$ \\
\hline
\end{tabular}

One or two grams of vitamin C per day resulted in the most applicable posology to increase the efficacy of CRP reduction (Table 4).

Table 5 shows the characteristics of the included systematic reviews of melatonin. Two SRs showed an effective action of this hormone in terms of reduction in IL-6, TNF-alpha and CRP. The follow-up duration ranged between 4 months and 60 weeks. The two studies considered subjects with chronic diseases and individuals affected by metabolic syndrome. 
Table 4. Vitamin C: summary of the principal characteristics of the included systematic reviews.

\begin{tabular}{|c|c|c|c|c|c|}
\hline Administration & Dose & Follow-Up & Endpoint & Efficacy & Study \\
\hline \multirow{2}{*}{ Intravenous } & $250 \mathrm{mg} /$ day & 8 weeks & CPR & Yes & Biniaz 2014 [24] \\
\hline & 300 mg/day & 24 weeks & CPR & Yes & Attallah 2006 [25] \\
\hline \multirow{4}{*}{ Oral } & $1 \mathrm{~g} /$ day & 10 days & $\mathrm{EF} *$ & Yes & De Marchi 2012 [26] \\
\hline & $1 \mathrm{~g} /$ day & 4 days & CRP & Yes & Colby 2011 [27] \\
\hline & $1 \mathrm{~g} /$ day & 4 weeks & CRP & Yes & Modi 2014 [28] \\
\hline & $2 \mathrm{~g} /$ day & 4 weeks & $\mathrm{EF}^{*}$ & Yes & $\begin{array}{c}\text { Antoniades } 2004 \text { [29] } \\
\text { Tousoulis } 2007 \text { [30] }\end{array}$ \\
\hline
\end{tabular}

* Endothelial function (EF) measured by either forearm blood flow (FBF) or flow mediated dilation (FMD).

Table 5. Melatonin: characteristics of the included systematic reviews.

\begin{tabular}{|c|c|c|}
\hline & Zarezadeh M (2019) [31] & Akbari M (2018) [32] \\
\hline Databases searched & $\begin{array}{l}\text { SCOPUS, PubMed, Cochrane Library, } \\
\text { Embase, Google Scholar }\end{array}$ & $\begin{array}{l}\text { Cochrane Library, EMBASE, PubMed, and } \\
\text { Web of Science }\end{array}$ \\
\hline Articles included & 13 & 6 \\
\hline Type of patients analyzed & Patients with chronic diseases & Patients with metabolic syndrome \\
\hline Posology & 3 to $25 \mathrm{mg} /$ day & 6 to $10 \mathrm{mg} /$ day \\
\hline Intervention duration range & From 4 to 60 weeks & From 4 weeks to 14 months \\
\hline Endpoint & $\begin{array}{c}\text { To evaluate the effect of supplementation } \\
\text { with melatonin on inflammatory biomarker } \\
\text { levels }\end{array}$ & $\begin{array}{c}\text { To evaluate the effect of supplementation } \\
\text { with melatonin on inflammatory markers } \\
\text { among subjects with MetS or related } \\
\text { disorders. }\end{array}$ \\
\hline Results & $\begin{array}{c}\text { Melatonin supplementation significantly } \\
\text { decreased TNF- } \alpha \text { and IL-6 levels } \\
{[(\mathrm{WMD}=-2.24 \mathrm{pg} / \mathrm{mL} ; 95 \% \mathrm{CI}-3.45} \\
-1.03 ; p<0.001 ; \mathrm{I} 2=96.7 \%, \text { Pheterogeneity }< \\
0.001) \text { and }(\mathrm{WMD}=-30.25 \mathrm{pg} / \mathrm{mL} ; 95 \% \mathrm{CI} \\
-41.45,-19.06 ; p<0.001,2 \mathrm{I}=99.0 \% ; \\
\text { Pheterogeneity }<0.001)], \text { respectively. The } \\
\text { effect of melatonin on CRP levels was } \\
\text { marginal. }\end{array}$ & $\begin{array}{l}\text { Melatonin supplementation significantly } \\
\text { reduced C-reactive protein (SMD }=-1.80 \\
95 \% \mathrm{CI}-3.27,-0.32 ; p=0.01 ; \mathrm{I} 2 \mathrm{9} \text {; } 95.2) \text { and } \\
\text { interleukin } 6(\mathrm{IL}-6) \text { concentrations } \\
(\mathrm{SMD}=-2.02 ; 95 \% \mathrm{CI}-3.57,-0.47 ; p=0.01 ; \\
\text { I2: } 91.2) \text { among patients with MetS and } \\
\text { related disorders; however, it did not affect } \\
\text { TNF- } \alpha \text { concentrations. }\end{array}$ \\
\hline Conclusions & $\begin{array}{l}\text { Melatonin supplementation significantly } \\
\text { reduced TNF- } \alpha \text { and IL- } 6 \text { levels. } \\
\text { The supplementation with melatonin } \\
\text { improved the levels of TNF- } \alpha \text { and IL- } 6 \text { more } \\
\text { efficiently in studies, which were conducted } \\
\text { for } \geq 12 \text { weeks and at a dosage } \geq 10 \mathrm{mg} / \text { day. }\end{array}$ & $\begin{array}{l}\text { The promising effect of melatonin } \\
\text { administration on reducing CRP and IL-6 } \\
\text { among patients with metabolic syndrome } \\
\text { and related disorders. }\end{array}$ \\
\hline
\end{tabular}

From the analysis of the included trials, a variety of employed dosages emerge (Table 6); a daily dose from 5 to $25 \mathrm{mg}$ daily has been reported, with similar efficacy.

Finally, we found only one SR of zinc supplementation summarizing 8 RCTs (Table 7). The intervention duration ranged between 6 and 25 weeks. The hemodialysis patients were considered. (Table 8).

Three RCTs had a positive effect on CRP reduction using $50 \mathrm{mg}$ of elemental zinc daily 
Table 6. Melatonin: summary of the principal characteristics of the included systematic reviews.

\begin{tabular}{|c|c|c|c|c|c|}
\hline Administration & Dose & Follow-Up & Endpoint & Efficacy & Study \\
\hline \multirow{6}{*}{ Oral } & $25 \mathrm{mg} /$ day & 26 weeks & TNF and IL-6 & Yes & SanchezLopez A (2018) [33] \\
\hline & $20 \mathrm{mg} /$ day & 12 weeks & TNF & Yes & Lissoni P (1996) [34] \\
\hline & \multirow{2}{*}{$10 \mathrm{mg} /$ day } & $\begin{array}{l}12 \text { weeks } \\
12 \text { weeks } \\
4 \text { weeks }\end{array}$ & CPR & Yes & $\begin{array}{l}\text { Raygan et al. (2017) [35] } \\
\text { Pakravan (2017) [36] } \\
\text { Javanmard (2016) [37] }\end{array}$ \\
\hline & & $\begin{array}{c}26 \text { weeks } \\
60 \text { weeks } \\
4 \text { weeks }\end{array}$ & TNF and IL-6 & Yes & $\begin{array}{c}\text { Forest CM (2007) [38] } \\
\text { Celinski et al. (2014) [39] } \\
\text { Cichoz-Lach et al. (2010) [40] }\end{array}$ \\
\hline & $6 \mathrm{mg} /$ day & 6 weeks & TNF and IL-6 & Yes & Mesri Alamdari (2015) [41] \\
\hline & $5 \mathrm{mg} /$ day & 52 weeks & CPR & Yes & Chojnacki C (2011) [42] \\
\hline
\end{tabular}

Table 7. Zinc: characteristics of the included systematic reviews.

\begin{tabular}{cc}
\hline Databases searched & Mousavi SM (2018) [43] \\
\hline Articles included & PubMed, SCOPUS, and Google Scholar \\
\hline Type of patients analyzed & Hemodialysis patients \\
\hline Posology & $50 \mathrm{mg} /$ day \\
\hline Intervention duration range & $6-25$ weeks \\
\hline Endpoint & $\begin{array}{c}\text { Effect of supplementation with zinc on plasma } \\
\text { CRP concentrations in adults }\end{array}$ \\
\hline Results & $\begin{array}{c}\text { The results of the meta-analysis displayed a significant reduction in circulating CRP } \\
\text { levels (WMD: }-1.68 \text { mg/L; 95\% CI: }-2.4 \text { to }-0.9, p=<0.001) \text { following } \\
\text { supplementation with zinc. }\end{array}$ \\
\hline Conclusions & Supplementation with zinc markedly reduced plasma CRP concentration \\
\hline
\end{tabular}

Table 8. Dose finding according to single trial results for zinc.

\begin{tabular}{cccccc}
\hline Administration & Dose & Follow-Up & Endpoint & Efficacy & Study \\
\hline \multirow{2}{*}{ Oral } & $50 \mathrm{mg} /$ day elemental zinc & 6 weeks & & & Rashidi (2009) [44] \\
& $(220 \mathrm{mg}$ zinc sulfate $)$ & 8 weeks & CPR & Yes & Tabrizi (2011) [45] \\
& & & & Jamilian (2016) [46] \\
\hline
\end{tabular}

\section{Discussion}

Pathophysiological basis of nutraceutical supplementation during the COVID-19 pandemic.

\subsection{Vitamin D}

Recently, the use of cholecalciferol was proposed as a beneficial measure to reduce the risk of COVID-19, in order to manage the pro-inflammatory milieu [47], and to reduce virus-induced iron dysmetabolism [48]. Literature data show a scenario of a world epidemic of cholecalciferol deficiency [49], which reaches $80 \%$ in elderly people, who have been shown to suffer from a higher COVID-19 mortality rate [50]. The intensity of the host immune/inflammatory response has repercussions on the clinical severity and mortality risk associated with viral diseases such as COVID-19, and this factor could be influenced by vitamin $\mathrm{D}$ deficiency. Due to the low $(20 \%)$ supply of cholecalciferol through dietary consumption, the supplementation of this pro-hormone has been suggested as beneficial 
in most chronic degenerative diseases. Specifically, active form calcitriol, a secosteroid hormone, can exert immuno-modulatory/anti-inflammatory activities, playing a role in the regulation of both innate and adaptive immunity; hence, in the COVID-19-related so-called "Cytokine storm", it is considered to be caused by the activation of the innate immune system and with an excessively increased activation of the adaptive immunity [51,52]. With regard to innate immunity, calcitriol can inhibit inflammatory $\mathrm{T}$ cell cytokines and Toll-like receptors present on monocytes. Moreover, high doses of calcitriol supplementation result in a significant reduction in IL-6 [53]. With regard to adaptive immunity, vitamin D also reduces excessive proliferation and immunoglobulin production in B cells; furthermore, it may suppress the differentiation of B cells into plasma cells [54]. Cholecalciferol can reduce the risk of the common viral influenza enhancing the epithelium physical barrier mechanism, as well as through the modulation of native and adaptive immunity [55]. In addition, vitamin $\mathrm{D}$ is related to the preservation of adhesion junctions, tight and gap junctions between epithelial cells, and their destruction represents the pathogenic mechanism of viral upper respiratory tract infection [56,57]. Concerning COVID-19, it has been hypothesized that the correction of vitamin deficiency suppresses CD26/DDP4, one of the adhesion molecules through which the COVID-19 virus and COVID-MERS virus enter into host cells [58-60]. Calcitriol could also directly affect SARS-CoV-2 infection through the anti-microbial cathelicidin family of peptides, particularly LL-37 [18]. This peptide may induce a viral membrane disruption via electrostatic interactions on the lipid envelopes of viruses $[18,19,61,62]$. Cardiovascular thrombotic events have been associated with the later stages of COVID-19, together with a high prevalence of pulmonary embolism, disseminated intravascular coagulation, liver, myocardial and renal failure [63,64]. Calcitriol was proven to exert some anticoagulant effects by upregulating the expression of anticoagulant thrombomodulin and downregulating the expression of critical coagulation factor in monocytes [65-67]. This virus-induced prothrombotic state is worsened in the case of heme release in the blood stream, which results in an upregulation of NLRP3 inflammasome [68,69]. Finally, it can enhance the expression of antioxidant-related genes [26], and increase the production of glutathione, thereby avoiding the use of ascorbic acid (vitamin C), which results in an antimicrobial activity [70-72], reducing the production of free radicals involved in inflammation which contribute to the pulmonary damage leading to the development of acute respiratory distress syndrome (ARDS) [70]. Moreover, vitamin D plays a crucial role in the reduction in proinflammatory cytokines, such as TNF $\alpha$ and IFN $\gamma$, involved in the pathogenesis of ARDS through the stimulation of Th2 and inhibition of Th1 [73-75]. Recently, a retrospective study has evaluated the clinical outcomes of 36 out of 91 COVID-19 patients receiving in-hospital high-dose cholecalciferol. During a follow-up period of approximately two weeks, logistic regression statistical analysis indicated that the positive effect of high-dose cholecalciferol on the combined endpoint was significantly augmented with growing comorbidity burden [76]. Moreover, the intermediate form of vitamin D Calcifediol was proposed as an additional treatment in COVID-19 patients, as it could significantly reduce the need for ICU treatment [77]. A recent systematic review and meta-analysis showed that low vitamin D serum levels were significantly associated with a higher risk of COVID-19 infection [78]. Regarding the severity of the disease, another systematic review highlights that subjects affected by severe COVID-19 present $65 \%$ more vitamin D deficiency in comparison to individuals affected by mild COVID-19. In addition, vitamin $\mathrm{D}$ deficiency was related to increased hospitalization and mortality from COVID-19 [79].

\subsection{Vitamin C}

The biomedical literature supports the role of ascorbic acid (AA) (vitamin C) in immunity regulation, anti-infective and anti-NLRP3 (namely, cytokine storm) activity [80-84]. In fact, this essential compound intervenes in a number of fundamental biochemical pathways of cell metabolism, including mitochondria functionality. These organelles undergo a high degree of oxidative stress and mitophagy during COVID-19 degenerative processes [85]. 
Vitamin $C$ was shown to prevent mitochondrial membrane depolarization and to combat mitochondrial DNA oxidative stress and cell toxicity, thus regulating fission and fusion processes $[86,87]$. Of interest, in the context of COVID-19-related hypoxia, AA interacts with hemoglobin to maintain heme iron in ferrous state, which is the only form to bind oxygen [88]. This exclusive beneficial activity on hemoglobin metabolism is best achieved by combining the supplementation of oral (L-AA) and intravenous AA $[48,89,90]$ Overall, clinical data have previously highlighted a significant role for AA among patients in ICU, with sepsis, pneumonia, multiorgan failure and ARDS [91]. Similarly, vitamin C immunomodulatory, anti-viral and anti-inflammatory properties have been repeatedly demonstrated in infective diseases $[72,80,92,93]$. The combination of these beneficial biochemical features has led several centers to assess high-dose AA supplementation as a complementary therapy in COVID-19 patients [91,94,95]. A few preliminary clinical studies on vitamin $\mathrm{C}$ in critical COVID-19 patients have shown some improvements in the oxygenation and interleukin-6 level, though a lower benefit for the mortality rate has been reported [96-98]. Conversely, a more pronounced effect of vitamin $C$ in combination with quercetin and bromelain seems to be effective, in terms of the prevention of COVID-19 infection in healthworkers [99]. Ongoing clinical trials will likely provide more evidence on the possible efficacy of vitamin C in COVID-19 patients. A randomized clinical trial is analyzing the efficacy and safety of high-dose vitamin $C$ in combination with Chinese medicine in the treatment of moderate and severe COVID-19 [100]. An uncontrolled longitudinal study is attempting to evaluate the efficacy and safety of $10 \mathrm{~g}$ of vitamin $\mathrm{C}$ intravenously in addition to conventional therapy in hospitalized patients with COVID-19 [101].

\subsection{Melatonin}

Melatonin (N-acetyl-5-methoxytryptamine) is a multifunctional hormone which is secreted mostly by the pineal gland and maximally at nighttime; [102] its secretion is extremely high in infants and adolescents, much lower in the elderly. Basically, this molecule helps to regulate many other hormones and maintains the body's circadian rhythm. Melatonin is significantly involved in the complex network of psycho-neuroendocrine immunology (PNEI), stress management and aging mechanisms [103]; furthermore, this compound interacts with cortisol and with a series of immunity and inflammasome pathways, which have been shown to derange in COVID-19 [104]. This molecule has been repeatedly considered a potentially useful compound in COVID-19 patients [48,105-107]. In fact, in these cases, it may reduce the documented extremely high mitochondria oxidative stress, namely, in lung cells [108], while conferring a general antioxidant action [42]. Melatonin was also recognized as a relevant modulator of innate and adaptive immune reactions [109] and specifically of the inflammasome NLRP3 $[110,111]$, the latter being a hyperactivated pathway in COVID-19 patients, contributing to the so-called "cytokine storm". This inflammasome downregulation also results in a reduction in pulmonary hypertension, which typically occurs in the critical stages during Sars-Cov-2 infection [112]. Lastly, melatonin is known to interact with CD147, a favorite Sars-Cov-2 cell receptor which is diffused in cell walls, erythrocyte and endothelium specifically. This specific feature has been regarded as a protective mechanism against a few pathologic pathways which may occur during COVID19 , such as hemoglobin denaturation, iron accumulation, hypoxia, cardiomyocytes injury and hypercoagulability $[104,106,113]$. Very preliminary clinical data correlate the better survival rate of COVID-19 intubated patients with melatonin exposure [114]; similarly, a small randomized clinical trial has shown a statistically significant improvement in clinical and instrumental findings in a group of patients treated additionally with melatonin, with a more rapid hospital discharge and return to baseline health [115]. A deregulation of tryptophan (precursor of melatonin) production has been demonstrated in COVID-19, which led a few authors to postulate the need of a greater supplementation with this hormone [116]. Of great interest, a recent multidrug repurposing study on 26,779 subjects affected by COVID-19 elucidated that higher melatonin levels were significantly associated with a $28 \%$ and $52 \%$ reduced likelihood of a SARS-CoV-2 infection in the general 
population and in African Americans, respectively [117]. The combination of the potential and demonstrated beneficial activities of melatonin, which is currently being investigated in a series of specific clinical trials, may pave the way to a greater employment of this compound in this pandemic [118].

\subsection{Zinc}

The transition metal zinc ( $\mathrm{Zn})$, after iron, is the second most abundant trace metal in the human body, and it is essential for multiple cellular functions, including the preservation of immune health, playing a critical role in antiviral immunity. Zn also acts as an anti-inflammatory agent and functions as an antioxidant, membrane stabilizer. Of interest, Zn deficiency can lead to immunodeficiency and severe lymphopenia, which is caused by a corresponding decrease in developing $\mathrm{B}$ cells in the bone marrow; furthermore, $\mathrm{Zn}$ potentiates a type-I Interferon (IFN) effect. Marked neutrophilia is detected in severe COVID-19 patients. Zn gluconate supplementation, inhibiting the NFkB-dependent transcription of inflammatory genes, is able to reduce airway neutrophil infiltration and TNF- $\alpha$ release. Zn supplementation may be able to reduce inflammatory cytokines (IL-6 and IL-1 $\beta$ ), enhancing the protective type-I IFN response in COVID-19 [119]. Zn inadequacy and deficiency are predicted to affect about $30 \%$ of the world population, in particular in the elderly; hence, the protective role of zinc supplementation against infection in the elderly population has been proposed [120]. Zn-deficient individuals experience increased susceptibility to pathogens, as well as some degree of ageusia and anosmia, emerging symptoms in COVID-19 patients [121,122]. Interestingly, coronavirus RNA polymerase activity appears to be inhibited by zinc [123], which could confer this metal a role in preventing coronavirus entry into cells [124] and reducing coronavirus virulency [125]. To date, scarce and contrasting clinical data on Zn supplementation efficacy on COVID-19 are available and particularly in the outpatient setting. A retrospective study including 141 individuals affected by COVID-19 in the general practice setting showed that zinc in combination with low-dose hydroxychloroquine was associated with significantly fewer hospitalizations [126]. On the contrary, in a recent randomized clinical trial of ambulatory COVID-19 patients, the administration of high-dose zinc gluconate or zinc gluconate combined with ascorbic acid did not significantly reduce the durability of symptoms in comparison with standard of care as well as hospitalizations and deaths [127].

\subsection{Evidence}

Regarding vitamin D, our review highlights a wide range of SRs, with different dosages and in different populations. The follow-up was between 1.5 months and 3 years. Different groups of patients were considered, including patients affected by diabetes, HIV, obese, elderly or featuring a high cardiovascular risk. Considering that different dosages of vitamin D (Table 2) showed a similar efficacy in CRP, the intake of 50,000 IU/month seems to be the proper dosage in terms of advantage and efficacy; moreover, this dose is in agreement both with the suggested dosage to reduce inflammatory activation and with the recommendations that advise not to exceed $4000 \mathrm{IU} /$ day, chronically. Regarding vitamin C, our review identified four high-quality SRs. The intervention duration ranged from 1 day to 52 weeks Different categories of patients were considered, including diabetic patients, subjects with chronic diseases and adult participants aged 18 years and older. The analysis of each single trial (Table 4) suggests that the effective dose is between 1 to $2 \mathrm{~g}$ per day both for CRP and endothelial function. Due to the impracticability of the intravenous administration within the community medicine policy, oral intake is recommended. With reference to melatonin, our review highlighted two SRs, both of high quality at AMSTAR evaluation. The follow-up duration ranged from 4 months to 60 weeks. The two studies considered subjects with chronic diseases and metabolic syndrome.

Melatonin seems to show good evidence of efficacy regarding the reduction in CRP, TNF and IL6, with a dosage ranging from 5 to $25 \mathrm{mg}$ /day (Table 7). However, the proper daily dose should be tailored to the age and clinical conditions of the patent, in order 
to avoid possible adverse effects, such as drowsiness. Literature data on zinc show a lower strength of evidence, in comparison to the other compounds. We found only one SR with an intervention duration between 6 and 25 weeks. The hemodialysis patients were included. The analysis of this single study (Table 8) showed positive results in CRP. A dosage of $50 \mathrm{mg} /$ day of elemental zinc supplementation was proposed to achieve an adequate efficacy.

\section{Conclusions}

According to the selected systematic reviews, vitamin $C$, vitamin $D$, melatonin and zinc nutraceuticals have anti-inflammatory actions. Hence, their large-scale utilization seems to represent a useful and viable approach during the COVID-19 pandemic. Adequate doses should be employed, following the most referenced literature data. Of importance, since no specific drug or other therapeutic or preventive measure has proven to be beneficial against the progression of COVID-19, this nutraceutical approach could have a role within a community-based medicine. However, it is to be highlighted that, to date, no systematic review has demonstrated a specific preventive effectiveness of these compounds in COVID19 , and many clinical trials are ongoing. In view of this missing evidence, further research is necessary and desirable to obtain more data on the employment of these natural molecules as a prevention and/or treatment in the COVID-19 pandemic. Other future clinical trials should be designed to assess the clinical benefits of each nutraceutical and/or of the combination of two or more of them. Nevertheless, it might be more useful to implement a therapeutic supplementation campaign for measuring the effects on the global population. Observational studies (a design before-after study or cluster quasi-experimental study), primarily focusing on outcomes such as hospital rates and mortality, would be useful to preliminarily assess the efficacy of these compounds. Overall, the possible support of the national health systems would be instrumental to guarantee an adequate provision of these nutraceuticals to the population. On the basis of the reported data in this review, public health systems, and subsequently the World Health Organization, could somehow take into account the possibility to complement current limited preventative measures/interventions with targeted nutraceutical large-scale administration.

Supplementary Materials: The following are available online at https:/ / www.mdpi.com/article/10 $.3390 /$ nu13041261/s1, Assessment of each systematic review by the AMSTAR tool.

Author Contributions: Conceptualization, S.C. and C.A.; methodology, S.C., G.N. and C.A.; software, G.N.; validation, S.C. and C.A.; formal analysis, R.M.B. and M.L.M.; investigation, R.M.B., M.L.M. and C.A.; resources, R.M.B. and M.L.M.; data curation, G.N., R.M.B. and M.L.M.; writing-original draft preparation, C.A.; writing-review and editing, S.C., A.C. and E.T.; visualization, G.N.; supervision, S.C.; project administration, C.A. All authors have read and agreed to the published version of the manuscript.

Funding: This research received no external funding.

Institutional Review Board Statement: Not applicable.

Informed Consent Statement: Not applicable.

Data Availability Statement: Not applicable.

Conflicts of Interest: The authors declare no conflict of interest.

\section{References}

1. Watkins, J. Preventing a covid-19 pandemic. BMJ 2020, 368, m810. [CrossRef] [PubMed]

2. Gupta, R.; Hussain, A.; Misra, A. Diabetes and COVID-19: Evidence, current status and unanswered research questions. Eur. J. Clin. Nutr. 2020, 74, 864-870. [CrossRef] [PubMed]

3. Wu, Z.; McGoogan, J.M. Characteristics of and Important Lessons from the Coronavirus Disease 2019 (COVID-19) Outbreak in China: Summary of a Report of 72314 Cases from the Chinese Center for Disease Control and Prevention. J. Am. Med. Assoc. 2020, 323, 1239-1242. [CrossRef] [PubMed]

4. Who Coronavirus Disease (COVID-19) Dashboard. Available online: https:/ / covid19.who.int/ (accessed on 23 January 2021). 
5. Li, Q.; Guan, X.; Wu, P.; Qun, L.; Xuhua, G.; Peng, W.; Xiaoye, W.; Lei, Z.; Yeqing, T.; Ruiqi, R.; et al. Early transmission dynamics in Wuhan, China, of Novel Coronavirus-Infected pneumonia. N. Engl. J. Med. 2020, 382, 1199-1207. [CrossRef] [PubMed]

6. Chaplin, D.D. Overview of the immune response. J. Allergy Clin. Immunol. 2010, 125 (Suppl. S2), S3-S23. [CrossRef]

7. Zabetakis, I.; Lordan, R.; Norton, C.; Tsoupras, A. COVID-19: The Inflammation Link and the Role of Nutrition in Potential Mitigation. Nutrients 2020, 12, 1466. [CrossRef]

8. Maggini, S.; Beveridge, S.; Sorbara, P.J.P.; Senatore, G. Feeding the immune system: The role of micronutrients in restoring resistance to infections. CAB Rev. 2008, 3, 1-21. [CrossRef]

9. Wu, C.; Chen, X.; Cai, Y.; Xia, J.; Zhou, X.; Xu, S.; Huang, H.; Zhang, L.; Zhou, X.; Du, C.; et al. Risk Factors Associated with Acute Respiratory Distress Syndrome and Death in Patients With Coronavirus Disease 2019 Pneumonia in Wuhan, China. JAMA Intern. Med. 2020, 180, 934-943. [CrossRef]

10. Herold, T.; Jurinovic, V.; Arnreich, C.; Lipworth, B.J.; Hellmuth, J.C.; Von Bergwelt-Baildon, M.; Klein, M.; Weinberger, T. Elevated levels of IL-6 and CRP predict the need for mechanical ventilation in COVID-19. J. Allergy Clin. Immunol. 2020, 146, 128-136.e4. [CrossRef]

11. Asbaghi, O.; Sadeghian, M.; Mozaffari-Khosravi, H.; Maleki, V.; Shokri, A.; Hajizadeh-Sharafabad, F.; Alizadeh, M.; Sadeghi, O. The effect of vitamin d-calcium co-supplementation on inflammatory biomarkers: A systematic review and meta-analysis of randomized controlled trials. Cytokine 2020, 129, 155050. [CrossRef]

12. Fisher, S.A.; Rahimzadeh, M.; Brierley, C.; Gration, B.; Doree, C.; Kimber, C.E.; Cajide, A.P.; Lamikanra, A.A.; Roberts, D.J. The role of vitamin $\mathrm{D}$ in increasing circulating $\mathrm{T}$ regulatory cell numbers and modulating $\mathrm{T}$ regulatory cell phenotypes in patients with inflammatory disease or in healthy volunteers: A systematic review. PLoS ONE 2019, 14, e0222313. [CrossRef] [PubMed]

13. Wang, M.; Liu, M.; Wang, C.; Xiao, Y.; An, T.; Zou, M.; Cheng, G. Association between vitamin D status and asthma control: A meta-analysis of randomized trials. Respir. Med. 2019, 150, 85-94. [CrossRef]

14. Yu, Y.; Tian, L.; Xiao, Y.; Huang, G.; Zhang, M. Effect of Vitamin D Supplementation on Some Inflammatory Biomarkers in Type 2 Diabetes Mellitus Subjects: A Systematic Review and Meta-Analysis of Randomized Controlled Trials. Ann. Nutr. Metab. 2018, 73, 62-73. [CrossRef]

15. Mazidi, M.; Rezaie, P.; Vatanparast, H. Impact of vitamin D supplementation on C-reactive protein; a systematic review and meta-analysis of randomized controlled trials. BMC Nutr. 2018, 4, 1. [CrossRef] [PubMed]

16. Calton, E.K.; Keane, K.N.; Newsholme, P.; Zhao, Y.; Soares, M.J. The impact of cholecalciferol supplementation on the systemic inflammatory profile: A systematic review and meta-analysis of high-quality randomized controlled trials. Eur. J. Clin. Nutr. 2017, 71, 931-943. [CrossRef] [PubMed]

17. Tari, A.; Freeborn, E.; Mushtaq, E. Impact of vitamin D supplementation on endothelial and inflammatory markers in adults: A systematic review. J. Steroid. Biochem. Mol. Biol. 2017, 173, 292-300.

18. Jamka, M.; Woźniewicz, M.; Walkowiak, J.; Bogdański, P.; Jeszka, J.; Stelmach-Mardas, M. The effect of vitamin D supplementation on selected inflammatory biomarkers in obese and overweight subjects: A systematic review with meta-analysis. Eur. J. Nutr. 2016, 55, 2163-2176. [CrossRef]

19. Chen, N.; Wan, Z.; Han, S.; Li, B.; Zhang, Z.; Qin, L. Effect of Vitamin D Supplementation on the Level of Circulating HighSensitivity C-Reactive Protein: A Meta-Analysis of Randomized Controlled Trials. Nutrients 2014, 6, 2206-2216. [CrossRef]

20. Safabakhsh, M.; Emami, M.R.; Khosroshahi, M.Z.; Asbaghi, O.; Khodayari, S.; Khorshidi, M.; Alizadeh, S.; Viri, E.H. Vitamin $\mathrm{C}$ supplementation and C-reactive protein levels: Findings from a systematic review and meta-analysis of clinical trials. J. Complement. Integr. Med. 2020. [CrossRef]

21. Jafarnejad, S.; Boccardi, V.; Hosseini, B.; Taghizadeh, M.; Hamedifard, Z. A Meta-analysis of Randomized Control Trials: The Impact of Vitamin C Supplementation on Serum CRP and Serum hs-CRP Concentrations. Curr. Pharm. Des. 2018, 24, 3520-3528. [CrossRef]

22. Ashor, A.W.; Siervo, M.; Lara, J.; Oggioni, C.; Afshar, S.; Mathers, J.C. Effect of vitamin C and vitamin E supplementation on endothelial function: A systematic review and meta-analysis of randomised controlled trials. Br. J. Nutr. 2015, 113, 1182-1194. [CrossRef] [PubMed]

23. Ashor, A.W.; Lara, J.; Mathers, J.C.; Siervo, M. Effect of vitamin C on endothelial function in health and disease: A systematic review and meta-analysis of randomised controlled trials. Atherosclerosis 2014, 235, 9-20. [CrossRef]

24. Biniaz, V.; Shermeh, M.S.; Ebadi, A.; Tayebi, A.; Einollahi, B. Effect of Vitamin C Supplementation on C-reactive Protein Levels in Patients Undergoing Hemodialysis: A Randomized, Double Blind, Placebo-Controlled Study. Nephro-Urol. Mon. 2013, 6, e13351. [CrossRef]

25. Attallah, N.; Osman-Malik, Y.; Frinak, S.; Besarab, A. Effect of Intravenous Ascorbic Acid in Hemodialysis Patients with EPO-Hyporesponsive Anemia and Hyperferritinemia. Am. J. Kidney Dis. 2006, 47, 644-654. [CrossRef]

26. De Marchi, S.; Prior, M.; Rigoni, A.; Zecchetto, S.; Rulfo, F.; Arosio, E. Ascorbic acid prevents vascular dysfunction induced by oral glucose load in healthy subjects. Eur. J. Intern. Med. 2012, 23, 54-57. [CrossRef] [PubMed]

27. Colby, J.A.; Chen, W.T.; Baker, W.L.; Coleman, C.I.; Reinhart, K.; Kluger, J.; White, C.M. Effect of ascorbic acid on inflammatory markers after cardiothoracic surgery. Am. J. Heal. Pharm. 2011, 68, 1632-1639. [CrossRef] [PubMed]

28. Modi, J.; Modi, P.; Pal, B.; Nagarajan, R.; Saifee, Y.; Bansal, J.; Kumar, S. Role of Vitamin C and E supplementation in reduction of serum level of renal injury marker following shock wave lithotripsy: Prospective single centre experience. Urol. Ann. 2015, 7, 350-354. [CrossRef] 
29. Antoniades, C.; Tousoulis, D.; Tountas, C.; Tentolouris, C.; Toutouza, M.; Vasiliadou, C.; Tsioufis, C.; Toutouzas, P.; Stefanadis, C. Vascular endothelium and inflammatory process, in patients with combined Type 2 diabetes mellitus and coronary atherosclerosis: The effects of vitamin C. Diabet. Med. 2004, 21, 552-558. [CrossRef] [PubMed]

30. Tousoulis, D.; Antoniades, C.; Vasiliadou, C.; Kourtellaris, P.; Koniari, K.; Marinou, K.; Charakida, M.; Ntarladimas, I.; Siasos, G.; Stefanadis, C. Effects of atorvastatin and vitamin C on forearm hyperaemic blood flow, asymmentrical dimethylarginine levels and the inflammatory process in patients with type 2 diabetes mellitus. Heart 2007, 93, 244-246. [CrossRef] [PubMed]

31. Zarezadeh, M.; Khorshidi, M.; Emami, M.; Janmohammadi, P.; Kord-Varkaneh, H.; Mousavi, S.M.; Mohammed, S.H.; Saedisomeolia, A.; Alizadeh, S. Melatonin supplementation and pro-inflammatory mediators: A systematic review and meta-analysis of clinical trials. Eur. J. Nutr. 2020, 59, 1803-1813. [CrossRef]

32. Akbari, M.; Ostadmohammadi, V.; Tabrizi, R.; Lankarani, K.B.; Heydari, S.T.; Amirani, E.; Reiter, R.J.; Asemi, Z. The effects of melatonin supplementation on inflammatory markers among patients with metabolic syndrome or related disorders: A systematic review and meta-analysis of randomized controlled trials. Inflammopharmacology 2018, 26, 899-907. [CrossRef]

33. Sánchez-López, A.; Ortiz, G.G.; Pacheco-Moises, F.P.; Mireles-Ramírez, M.A.; Bitzer-Quintero, O.K.; Delgado-Lara, D.L.C.; Ramírez-Jirano, L.J.; Velázquez-Brizuela, I.E. Efficacy of Melatonin on Serum Pro-inflammatory Cytokines and Oxidative Stress Markers in Relapsing Remitting Multiple Sclerosis. Arch. Med. Res. 2018, 49, 391-398. [CrossRef] [PubMed]

34. Lissoni, P.; Paolorossi, F.; Tancini, G.; Barni, S.; Ardizzoia, A.; Brivio, F.; Zubelewicz, B.; Chatikhine, V. Is there a role for melatonin in the treatment of neoplastic cachexia? Eur. J. Cancer 1996, 32, 1340-1343. [CrossRef]

35. Raygan, F.; Ostadmohammadi, V.; Bahmani, F.; Reiter, R.J.; Asemi, Z. Melatonin administration lowers biomarkers of oxidative stress and cardio-metabolic risk in type 2 diabetic patients with coronary heart disease: A randomized, double-blind, placebocontrolled trial. Clin. Nutr. 2019, 38, 191-196. [CrossRef] [PubMed]

36. Pakravan, H.; Ahmadian, M.; Fani, A.; Aghaee, D.; Brumanad, S.; Pakzad, B. The Effects of melatonin in patients with nonalcoholic fatty liver disease: A randomized controlled trial. Adv. Biomed. Res. 2017, 6, 40.

37. Javanmard, S.; Heshmat-Ghahdarijani, K.; Mirmohammad-Sadeghi, M.; Sonbolestan, S.A.; Ziayi, A. The effect of melatonin on endothelial dysfunction in patient undergoing coronary artery bypass grafting surgery. Adv. Biomed. Res. 2016, 5, 174.

38. Forrest, C.M.; Mackay, G.M.; Stoy, N.; Stone, T.W.; Darlington, L.G. Inflammatory status and kynurenine metabolism in rheumatoid arthritis treated with melatonin. Br. J. Clin. Pharmacol. 2007, 64, 517-526. [CrossRef]

39. Celinski, K.; Konturek, P.; Slomka, M.; Cichoz-Lach, H.; Brzozowski, T.; Konturek, S.J.; Korolczuk, A. Effects of treatment with melatonin and tryptophan on liver enzymes, parameters of fat metabolism and plasma levels of cytokines in patients with nonalcoholic fatty liver disease-14 months follow up. J. Physiol. Pharmacol. 2014, 65, 75-82.

40. Cichoz-Lach, H.; Celinski, K.; Konturek, P.C.; Konturek, S.J.; Slomka, M. The effects of 1-tryptophan and melatonin on selected biochemical parameters in patients with steatohepatitis. J. Physiol. Pharmacol. 2010, 61, 577-580.

41. Alamdari, N.M.; Mahdavi, R.; Roshanravan, N.; Yaghin, N.L.; Ostadrahimi, A.R.; Faramarzi, E. A Double-Blind, PlaceboControlled Trial Related to the Effects of Melatonin on Oxidative Stress and Inflammatory Parameters of Obese Women. Horm. Metab. Res. 2015, 47, 504-508. [CrossRef]

42. Chojnacki, C.; Wisniewska-Jarosinska, M.; Walecka-Kapica, E.; Klupinska, G.; Jaworek, J.; Chojnacki, J. Evaluation of melatonin effectiveness in the adjuvant treatment of ulcerative colitis. J. Physiol. Pharmacol. 2011, 62, 327-334.

43. Mousavi, S.M.; Djafarian, K.; Mojtahed, A.; Varkaneh, H.K.; Shab-Bidar, S. The effect of zinc supplementation on plasma C-reactive protein concentrations: A systematic review and meta-analysis of randomized controlled trials. Eur. J. Pharmacol. 2018, 834, 10-16. [CrossRef]

44. Rashidi, A.A.; Salehi, M.; Piroozmand, A.; Sagheb, M.M. Effects of zinc supplementation on serum zinc and C-reactive protein concentrations in hemodialysis patients. J. Ren. Nutr. 2009, 19, 475-478. [CrossRef]

45. Pourteymour Fard Tabrizi, F.; Alipoor, B.; Ostadrahimi, A.R.; Mehrzad Sadagiani, M. Effect of zinc supplementation on inflammatory markers in women with polycystic ovary syndrome. Shiraz E Med. J. 2011, 12, 30-38.

46. Jamilian, M.; Foroozanfard, F.; Bahmani, F.; Talaee, R.; Monavari, M.; Asemi, Z. Effects of Zinc Supplementation on Endocrine Outcomes in Women with Polycystic Ovary Syndrome: A Randomized, Double-Blind, Placebo-Controlled Trial. Biol. Trace Elem. Res. 2016, 170, 271-278. [CrossRef]

47. Grant, W.B.; Lahore, H.; McDonnell, S.L.; Baggerly, C.A.; French, C.B.; Aliano, J.L.; Bhattoa, H.P. Evidence that Vitamin D Supplementation Could Reduce Risk of Influenza and COVID-19 Infections and Deaths. Nutrients 2020, 12, 988. [CrossRef]

48. Cavezzi, A.; Troiani, E.; Corrao, S. COVID-19: Hemoglobin, Iron, and Hypoxia beyond Inflammation. A Narrative Review. Clin. Pr. 2020, 10, 24-30. [CrossRef]

49. Bandeira, F.; Griz, L.; Dreyer, P.; Eufrazino, C.; Bandeira, C.; Freese, E. Vitamin D deficiency: A global perspective. Arq. Bras. Endocrinol. Metabol. 2006, 50, 640-646. [CrossRef]

50. Shahid, Z.; Bs, R.K.; Bs, B.M.; Kepko, D.; Bs, D.R.; Patel, R.; Mbbs, C.S.A.; Vunnam, R.R.; Sahu, N.; Bhatt, D.; et al. COVID-19 and Older Adults: What We Know. J. Am. Geriatr. Soc. 2020, 68, 926-929. [CrossRef]

51. Ragab, D.; Eldin, H.S.; Taeimah, M.; Khattab, R.; Salem, R. The COVID-19 Cytokine Storm; What We Know So Far. Front. Immunol. 2020, 11, 1446. [CrossRef] [PubMed]

52. Lipsky, M.; Hung, M. Men and COVID-19: A pathophysiologic review. Am. J. Mens Health 2020, 14, 1557988320954021. [CrossRef]

53. Cutolo, M.; Paolino, S.; Smith, V. Evidences for a protective role of vitamin D in COVID-19. RMD Open 2020, 6, e001454. [CrossRef] [PubMed] 
54. Cyprian, F.; Lefkou, E.; Varoudi, K.; Girardi, G. Immunomodulatory Effects of Vitamin D in Pregnancy and Beyond. Front. Immunol. 2019, 10, 2739. [CrossRef]

55. Rondanelli, M.; Miccono, A.; Lamburghini, S.; Avanzato, I.; Riva, A.; Allegrini, P.; Faliva, M.A.; Peroni, G.; Nichetti, M.; Perna, S. Self-Care for Common Colds: The Pivotal Role of Vitamin D, Vitamin C, Zinc, and Echinacea in Three Main Immune Interactive Clusters (Physical Barriers, Innate and Adaptive Immunity) Involved during an Episode of Common Colds-Practical Advice on Dosages and on the Time to Take These Nutrients/Botanicals in order to Prevent or Treat Common Colds. Evid. Based Complement. Altern. Med. 2018, 2018, 5813095.

56. Schwalfenberg, G.K. A review of the critical role of vitamin D in the functioning of the immune system and the clinical implications of vitamin D deficiency. Mol. Nutr. Food Res. 2011, 55, 96-108. [CrossRef]

57. Kast, J.I.; McFarlane, A.J.; Głobin'ska, A.; Sokolowska, M.; Wawrzyniak, P.; Sanak, M.; Schwarze, J.; Akdis, C.A.; Wanke, K. Respiratory syncytial virus infection influences tight junction integrity. Clin. Exp. Immunol. 2017, 190, 351-359. [CrossRef]

58. McCartney, D.M.; Byrne, D.G. Optimisation of vitamin D status for enhanced immuno-protection against CoViD-19. Ir. Med. J. 2020, 113, 58 .

59. Vankadari, N.; Wilce, J.A. Emerging WuHan (COVID-19) coronavirus: Glycan shield and structure prediction of spike glycoprotein and its interaction with human CD26. Emerg. Microbes Infect. 2020, 9, 601-604. [CrossRef]

60. Skariyachan, S.; Challapilli, S.B.; Packirisamy, S.; Kumargowda, S.T.; Sridhar, V.S. Recent aspects on the pathogenesis mechanism, animal models and novel therapeutic interventions for middle-east respiratory syndrome coronavirus infections. Front. Microbiol. 2019, 10, 569. [CrossRef]

61. Beard, J.A.; Bearden, A.; Striker, R. Vitamin D and the anti-viral state. J. Clin. Virol. 2011, 50, 194-200. [CrossRef]

62. Teymoori-Rad, M.; Shokri, F.; Salimi, V.; Marashi, S.M. The interplay between vitamin D and viral infections. Rev. Med Virol. 2019, 29, e2032. [CrossRef]

63. Bikdeli, B.; Madhavan, M.V.; Jimenez, D.; Chuich, T.; Dreyfus, I.; Driggin, E.; Der Nigoghossian, C.; Ageno, W.; Madjid, M.; Guo, Y.; et al. COVID-19 and Thrombotic or Thromboembolic Disease: Implications for Prevention, Antithrombotic Therapy, and Follow-Up: JACC State-of-the-Art Review. J. Am. Coll. Cardiol. 2020, 75, 2950-2973. [CrossRef]

64. Zaim, S.; Chong, J.H.; Sankaranarayanan, V.; Harky, A. COVID-19 and Multiorgan Response. Curr. Probl. Cardiol. 2020, 45, 100618. [CrossRef]

65. Gagnon, C.; Daly, R.M.; Carpentier, A.; Lu, Z.X.; Shore-Lorenti, C.; Sikaris, K.; Jean, S.; Ebeling, P.R. Effects of Combined Calcium and Vitamin D Supplementation on Insulin Secretion, Insulin Sensitivity and $\beta$-Cell Function in Multi-Ethnic Vitamin D-Deficient Adults at Risk for Type 2 Diabetes: A Pilot Randomized, Placebo-Controlled Trial. PLoS ONE 2014, 9, e109607. [CrossRef] [PubMed]

66. Aihara, K.-I.; Azuma, H.; Akaike, M.; Ikeda, Y.; Yamashita, M.; Sudo, T.; Hayashi, H.; Yamada, Y.; Endoh, F.; Fujimura, M.; et al. Disruption of Nuclear Vitamin D Receptor Gene Causes Enhanced Thrombogenicity in Mice. J. Biol. Chem. 2004, 279, 35798-35802. [CrossRef] [PubMed]

67. Wu-Wong, J.R.; Nakane, M.; Ma, J. Vitamin D Analogs Modulate the Expression of Plasminogen Activator Inhibitor-1, Thrombospondin-1 and Thrombomodulin in Human Aortic Smooth Muscle Cells. J. Vasc. Res. 2007, 44, 11-18. [CrossRef]

68. Gomes, T.; Várady, C.B.S.; Lourenço, A.L.; Mizurini, D.M.; Rondon, A.M.R.; Leal, A.C.; Gonçalves, B.S.; Bou-Habib, D.C.; Medei, E.; Monteiro, R.Q. IL-1 $\beta$ Blockade Attenuates Thrombosis in a Neutrophil Extracellular Trap-Dependent Breast Cancer Model. Front. Immunol. 2019, 10, 2088. [CrossRef]

69. Erdei, J.; Tóth, A.; Balogh, E.; Nyakundi, B.B.; Bányai, E.; Ryffel, B.; Paragh, G.; Cordero, M.D.; Jeney, V. Induction of NLRP3 Inflammasome Activation by Heme in Human Endothelial Cells. Oxidative Med. Cell. Longev. 2018, 2018, 4310816. [CrossRef] [PubMed]

70. Lei, G.-S.; Zhang, C.; Cheng, B.; Lee, C.-H. Mechanisms of Action of Vitamin D as Supplemental Therapy for Pneumocystis Pneumonia. Antimicrob. Agents Chemother. 2017, 61, e01226-17. [CrossRef]

71. Mousavi, S.; Bereswill, S.; Heimesaat, M.M. Immunomodulatory and Antimicrobial Effects of Vitamin C. Eur. J. Microbiol. Immunol. 2019, 9, 73-79. [CrossRef] [PubMed]

72. Colunga Biancatelli, R.; Berrill, M.; Marik, P. The antiviral properties of vitamin C. Expert Rev. Anti-Infect. Ther. 2019, 18, 99-101. [CrossRef]

73. Cantorna, M.T.; Snyder, L.; Lin, Y.D.; Yang, L. Vitamin D and 1,25(OH)2D regulation of T cells. Nutrients 2015, 7, 3011-3021. [CrossRef]

74. Jeffery, L.E.; Burke, F.; Mura, M.; Zheng, Y.; Qureshi, O.S.; Hewison, M.; Walker, L.S.K.; Lammas, D.A.; Raza, K.; Sansom, D.M. 1,25-Dihydroxyvitamin D 3 and IL-2 combine to inhibit T cell production of inflammatory cytokines and promote development of regulatory T cells expressing CTLA-4 and foxp3. J. Immunol. 2009, 183, 5458-5467. [CrossRef]

75. Lin, S.; Wu, H.; Wang, C.; Xiao, Z.; Xu, F. Regulatory T cells and acute lung injury: Cytokines, uncontrolled inflammation, and therapeutic implications. Front. Immunol. 2018, 9, 1545. [CrossRef]

76. Giannini, S.; Passeri, G.; Tripepi, G.; Sella, S.; Fusaro, M.; Arcidiacono, G.; Torres, M.O.; Michielin, A.; Prandini, T.; Baffa, V.; et al. Effectiveness of In-Hospital Cholecalciferol Use on Clinical Outcomes in Comorbid COVID-19 Patients: A Hypothesis-Generating Study. Nutrients 2021, 13, 219. [CrossRef] 
77. Castillo, M.E.; Costa, L.M.E.; Barrios, J.M.V.; Díaz, J.F.A.; Miranda, J.L.; Bouillon, R.; Gomez, J.M.Q. Effect of calcifediol treatment and best available therapy versus best available therapy on intensive care unit admission and mortality among patients hospitalized for COVID-19: A pilot randomized clinical study. J. Steroid. Biochem. Mol. Biol. 2020, 203, 105751. [CrossRef]

78. Teshome, A.; Adane, A.; Girma, B.; Mekonnen, Z.A. The Impact of Vitamin D Level on COVID-19 Infection: Systematic Review and Meta-Analysis. Front. Public Heal. 2021, 9, 624559. [CrossRef]

79. Pereira, M.; Dantas Damascena, A.; Galvão Azevedo, L.M.; de Almeida Oliveira, T.; da Mota Santana, J. Vitamin D deficiency aggravates COVID-19: Systematic review and meta-analysis. Crit. Rev. Food Sci. Nutr. 2020, 1-9. [CrossRef]

80. Hemilä, H. Vitamin C and SARS coronavirus. J. Antimicrob. Chemother. 2003, 52, 1049-1050. [CrossRef] [PubMed]

81. Choe, J.-Y.; Kim, S.-K. Quercetin and Ascorbic Acid Suppress Fructose-Induced NLRP3 Inflammasome Activation by Blocking Intracellular Shuttling of TXNIP in Human Macrophage Cell Lines. Inflammation 2017, 40, 980-994. [CrossRef] [PubMed]

82. Hemila, H. Vitamin C supplementation and respiratory infections: A systematic review. Mil. Med. 2004, 169, 920-925. [CrossRef]

83. Boretti, A.; Bimal, K. Intravenous vitamin C for reduction of cytokines storm in acute respiratory distress syndrome. PharmaNutrition 2020, 12, 100190. [CrossRef]

84. Jovic, T.H.; Ali, S.R.; Ibrahim, N.; Jessop, Z.M.; Tarassoli, S.P.; Dobbs, T.D.; Holford, P.; Thornton, C.A.; Whitaker, I.S. Could Vitamins Help in the Fight Against COVID-19? Nutrients 2020, 12, 2550. [CrossRef]

85. Saleh, J.; Peyssonnaux, C.; Singh, K.K.; Edeas, M. Mitochondria and microbiota dysfunction in COVID-19 pathogenesis. Mitochondrion 2020, 54, 1-7. [CrossRef]

86. Cantoni, O.; Guidarelli, A.; Fiorani, M. Mitochondrial Uptake and Accumulation of Vitamin C: What Can We Learn from Cell Culture Studies? Antioxidants Redox Signal. 2018, 29, 1502-1515. [CrossRef] [PubMed]

87. Kc, S.; Càrcamo, J.M.; Golde, D.W. Vitamin C enters mitochondria via facilitative glucose transporter 1 (Gluti) and confers mitochondrial protection against oxidative injury. FASEB J. 2005, 19, 1657-1667. [CrossRef] [PubMed]

88. VanDuijn, M.M.; Tijssen, K.; VanSteveninck, J.; Broek, P.J.V.D.; Van der Zee, J. Erythrocytes Reduce Extracellular Ascorbate Free Radicals Using Intracellular Ascorbate as an Electron Donor. J. Biol. Chem. 2000, 275, 27720-27725. [CrossRef]

89. Padayatty, S.J.; Sun, H.; Wang, Y.; Riordan, H.D.; Hewitt, S.M.; Katz, A.; Wesley, R.A.; Levine, M. Vitamin C Pharmacokinetics: Implications for Oral and Intravenous Use. Ann. Intern. Med. 2004, 140, 533-537. [CrossRef]

90. Fonorow, O.; Hickey, S. Unexpected Early Response in Oral Bioavailability of Ascorbic Acid. Townsend Lett. 2020, 52. Available online: https: / / www.townsendletter.com/article/online (accessed on 13 March 2021).

91. Richard, Z. Can early and high intravenous dose of vitamin C prevent and treat coronavirus disease 2019 (COVID-19)? Med. Drug Discov. 2020, 5, 100028.

92. Cerullo, G.; Negro, M.; Parimbelli, M.; Pecoraro, M.; Perna, S.; Liguori, G.; Rondanelli, M.; Cena, H.; D'Antona, G. The Long History of Vitamin C: From Prevention of the Common Cold to Potential Aid in the Treatment of COVID-19. Front. Immunol. 2020, 11, 574029. [CrossRef]

93. Carr, A.C.; Maggini, S. Vitamin C and Immune Function. Nutrients 2017, 9, 1211. [CrossRef]

94. Zhang, W.; Lu, H.; Shanghai Clinical Treatment Expert Group for Coronavirus Disease 2019. Comprehensive treatment and management of corona virus disease 2019: Expert consensus statement from Shanghai. Chin. J. Infect. Dis. 2020, 38. [CrossRef]

95. Holford, P.; Carr, A.C.; Jovic, T.H.; Ali, S.R.; Whitaker, I.S.; Marik, P.E.; Smith, A.D. Vitamin C-An Adjunctive Therapy for Respiratory Infection, Sepsis and COVID-19. Nutrients 2020, 12, 3760. [CrossRef] [PubMed]

96. Zhang, J.; Rao, X.; Li, Y.; Zhu, Y.; Liu, F.; Guo, G.; Luo, G.; Meng, Z.; De Backer, D.; Xiang, H.; et al. Pilot trial of high-dose vitamin $\mathrm{C}$ in critically ill COVID-19 patients. Ann. Intensiv. Care 2021, 11, 1-12. [CrossRef] [PubMed]

97. Kumari, P.; Dembra, S.; Dembra, P.; Bhawna, F.; Gul, A.; Ali, B.; Sohail, H.; Kumar, B.; Memon, M.K.; Rizwan, A. The Role of Vitamin $\mathrm{C}$ as Adjuvant Therapy in COVID-19. Cureus 2020, 12. [CrossRef]

98. Zhao, B.; Ling, Y.; Li, J.; Peng, Y.; Huang, J.; Wang, Y.; Qu, H.; Gao, Y.; Li, Y.; Hu, B.; et al. Beneficial aspects of high dose intravenous vitamin $\mathrm{C}$ on patients with COVID-19 pneumonia in severe condition: A retrospective case series study. Ann. Palliat. Med. 2021, 10, 1599-1609. [CrossRef]

99. Arslan, B.; Ergun, N.U.; Topuz, S.; Semerci, S.Y.; Suner, N.; Kocatas, A.; Onal, H. Synergistic Effect of Quercetin and Vitamin C Against COVID-19: Is a Possible Guard for Front Liners. SSRN Electron. J. 2020. [CrossRef]

100. ClinicalTrial.gov. U.S National Library of Medicine. Available online: https://clinicaltrials.gov/ct2/show / NCT04664010?term= vitamin + c\&cond=covid-19\&draw $=2 \&$ rank $=1$ (accessed on 3 April 2021).

101. ClinicalTrial.gov. U.S National Library of Medicine. Available online: https:/ clinicaltrials.gov/ct2/show/NCT04323514?term= vitamin + c\&cond=covid-19\&draw $=2$ (accessed on 3 April 2021).

102. Scholtens, R.M.; Van Munster, B.C.; Van Kempen, M.F.; De Rooij, S.E.J.A. Physiological melatonin levels in healthy older people: A systematic review. J. Psychosom. Res. 2016, 86, 20-27. [CrossRef]

103. Cavezzi, A.; Ambrosini, L.; Colucci, R.; Ionna, G.D.; Urso, S.U. Aging in the Perspective of Integrative Medicine, Psychoneuroendocrineimmunology and Hormesis. Curr. Aging Sci. 2020, 13, 82-91. [CrossRef]

104. Tan, D.X.; Hardeland, R. Potential utility of melatonin in deadly infectious diseases related to the overreaction of innate immune response and destructive inflammation: Focus on COVID-19. Melatonin Res. 2020, 3, 120-143. [CrossRef]

105. Zhang, R.; Wang, X.; Ni, L.; Di, X.; Ma, B.; Niu, S.; Liu, C.; Reiter, R.J. COVID-19: Melatonin as a potential adjuvant treatment. Life Sci. 2020, 250, 117583. [CrossRef] 
106. Loh, D. The potential of melatonin in the prevention and attenuation of oxidative hemolysis and myocardial injury from cd147 SARS-CoV-2 spike protein receptor binding. Melatonin Res. 2020, 3, 380-416. [CrossRef]

107. Juybari, K.B.; Pourhanifeh, M.H.; Hosseinzadeh, A.; Hemati, K.; Mehrzadi, S. Melatonin potentials against viral infections including COVID-19: Current evidence and new findings. Virus Res. 2020, 287, 198108. [CrossRef] [PubMed]

108. Acuña-Castroviejo, D.; Carretero, M.; Doerrier, C.; López, L.C.; García-Corzo, L.; Tresguerres, J.A.; Escames, G. Melatonin protects lung mitochondria from aging. AGE 2011, 34, 681-692. [CrossRef] [PubMed]

109. Carrillo-Vico, A.; Lardone, P.J.; Álvarez-Sánchez, N.; Rodríguez-Rodríguez, A.; Guerrero, J.M. Melatonin: Buffering the Immune System. Int. J. Mol. Sci. 2013, 14, 8638-8683. [CrossRef] [PubMed]

110. Volt, H.; García, J.A.; Doerrier, C.; Díaz-Casado, M.E.; Guerra-Librero, A.; López, L.C.; Escames, G.; Tresguerres, J.A.; Acuña-Castroviejo, D. Same molecule but different expression: Aging and sepsis trigger NLRP3 inflammasome activation, a target of melatonin. J. Pineal Res. 2016, 60, 193-205. [CrossRef] [PubMed]

111. Zhang, Y.; Li, X.; Grailer, J.J.; Wang, N.; Wang, M.; Yao, J.; Zhong, R.; Gao, G.F.; Ward, P.A.; Tan, D.-X.; et al. Melatonin alleviates acute lung injury through inhibiting the NLRP3 inflammasome. J. Pineal Res. 2016, 60, 405-414. [CrossRef] [PubMed]

112. Zhang, J.; Lu, X.; Liu, M.; Fan, H.; Zheng, H.; Zhang, S.; Rahman, N.; Wołczyński, S.; Kretowski, A.; Li, X. Melatonin inhibits inflammasome-associated activation of endothelium and macrophages attenuating pulmonary arterial hypertension. Cardiovasc. Res. 2020, 116, 2156-2169. [CrossRef]

113. Sehirli, A.O.; Sayiner, S.; Serakinci, N. Role of melatonin in the treatment of COVID-19; as an adjuvant through cluster differentiation 147 (CD147). Mol. Biol. Rep. 2020, 47, 8229-8233. [CrossRef]

114. Ramlall, V.; Zucker, J.; Tatonetti, N. Melatonin is significantly associated with survival of intubated COVID-19 patients. medRxiv 2020. [CrossRef]

115. Farnoosh, G.; Akbariqomi, M.; Badri, T.; Bagheri, M.; Izadi, M.; Saeedi-Boroujeni, A.; Rezaie, E.; Ghaleh, H.E.G.; Aghamollaei, H.; Fasihi-Ramandi, M.; et al. Efficacy of a Low Dose of Melatonin as an Adjunctive Therapy in Hospitalized Patients with COVID-19: A Randomized, Double-blind Clinical Trial. Authorea Prepr. 2020. [CrossRef]

116. Essa, M.M.; Hamdan, H.; Chidambaram, S.B.; Al-Balushi, B.; Guillemin, G.J.; Ojcius, D.M.; Qoronfleh, M.W. Possible role of tryptophan and melatonin in COVID-19. Int. J. Tryptophan Res. 2020, 13. [CrossRef] [PubMed]

117. Zhou, Y.; Hou, Y.; Shen, J.; Mehra, R.; Kallianpur, A.; Culver, D.A.; Gack, M.U.; Farha, S.; Zein, J.; Comhair, S.; et al. A network medicine approach to investigation and population-based validation of disease manifestations and drug repurposing for COVID-19. PLoS Biol. 2020, 18, e3000970. [CrossRef] [PubMed]

118. Cardinali, D.P.; Brown, G.M.; Pandi-Perumal, S.R. Can Melatonin Be a Potential "Silver Bullet" in Treating COVID-19 Patients? Diseases 2020, 8, 44. [CrossRef]

119. Pal, A.; Squitti, R.; Picozza, M.; Pawar, A.; Rongioletti, M.; Dutta, A.K.; Sahoo, S.; Goswami, K.; Sharma, P.; Prasad, R. Zinc and COVID-19: Basis of Current Clinical Trials. Biol. Trace Elem. Res. 2020. [CrossRef]

120. Wu, D.; Lewis, E.D.; Pae, M.; Meydani, S.N. Nutritional Modulation of Immune Function: Analysis of Evidence, Mechanisms, and Clinical Relevance. Front. Immunol. 2018, 9, 3160. [CrossRef]

121. Shankar, A.H.; Prasad, A.S. Zinc and immune function: The biological basis of altered resistance to infection. Am. J. Clin. Nutr. 1998, 68 (Suppl. S2), 447S-463S. [CrossRef]

122. Tomita, H. Zinc in taste and smell disorder. Trace Elem. Clin. Med. 1990, 15-37. [CrossRef]

123. Velthuis, A.J.W.T.; Worm, S.H.E.V.D.; Sims, A.C.; Baric, R.S.; Snijder, E.J.; Van Hemert, M.J. Zn2+ Inhibits Coronavirus and Arterivirus RNA Polymerase Activity In Vitro and Zinc Ionophores Block the Replication of These Viruses in Cell Culture. PLoS Pathog. 2010, 6, e1001176. [CrossRef] [PubMed]

124. Phillips, J.M.; Gallagher, T.; Weiss, S.R. Neurovirulent murine coronavirus JHM.SD uses cellular zinc metalloproteases for virus entry and cell-cell fusion. J. Virol. 2017, 91. [CrossRef]

125. Han, Y.-S.; Chang, G.-G.; Juo, C.-G.; Lee, H.-J.; Yeh, S.-H.; Hsu, J.T.-A.; Chen, X. Papain-like protease 2 (PLP2) from severe acute respiratory syndrome coronavirus (SARS-CoV): Expression, purification, characterization, and inhibition. Biochemistry 2005, 44, 10349-10359. [CrossRef] [PubMed]

126. Derwand, R.; Scholz, M.; Zelenko, V. COVID-19 outpatients: Early risk-stratified treatment with zinc plus low-dose hydroxychloroquine and azithromycin: A retrospective case series study. Int. J. Antimicrob. Agents 2020, 56, 106214. [CrossRef] [PubMed]

127. Thomas, S.; Patel, D.; Bittel, B.; Wolski, K.; Wang, Q.; Kumar, A.; Il'Giovine, Z.J.; Mehra, R.; McWilliams, C.; Nissen, S.E.; et al. Effect of High-Dose Zinc and Ascorbic Acid Supplementation vs Usual Care on Symptom Length and Reduction Among Ambulatory Patients With SARS-CoV-2 Infection. JAMA Netw. Open 2021, 4, e210369. [CrossRef] [PubMed] 